УДК 373.2.015.31

DOI:

Лариса Журавльова, кандидат педагогічних наук, доиент кафедри соиіальної роботи, соиіальної педагогіки та дошкільної освіти Мелітопольського державного педагогічного університету імені Богдана Хмельницького

Каріна Іпкаєва, студентка магістратури

Мелітопольського державного педагогічного університету імені Богдана Хмельницького

\title{
ФОРМУВАННЯ ТВОРЧИХ ЗДІБНОСТЕЙ СТАРШИХ ДОШКІЛЬНИКІВ ЗАСОБАМИ ІНТЕГРАЦІЇ РІЗНИХ ВИДІВ ХУДОЖНЬОЇ-ТВОРЧОЇ ДІЯЛЬНОСТІ
}

У статті висвітлені теоретичні питання формування творчих здібностей старших дошкільників засобами інтеграчії різних видів художньо-творчої діяльності. Розкрито зміст понять “інтеграція”, “образотворча діяльність", “театральна діяльність", “творчі здібності” у сучасній педагогічній літературі. Здійснено спробу довести, що інтеграчія образотворчої і театральної діяльності для стариих дошкільників буде ефективним засобом формування творчих здібностей.

Ключові слова: стариі дошкільники; інтеграція; образотворча діяльність; театральна діяльність; творчі здібності.

תim. 11.

Larysa Zhuravlova, Ph.D.(Pedagogy),Associate Professor of the Social Work, Social Pedagogy and Pre-school Education Department Melitopol Bohdan Khmelnytskiy State Pedagogical University

Karina Ipkayeva, Master's Student Melitopol Bohdan Khmelnytskiy State Pedagogical University

\section{FORMATION OFCREATIVE ABILITIES OF SENIOR PRESCHOOL CHILDREN BY MEANS OF INTEGRATION OF VARIOUS TYPES OFARTISTIC AND CREATIVEACTIVITY}

In the article the theoretical questions of formation of creative abilities of senior preschool children by means of integration of various types of artistic and creative activities are highlighted. The content of the concepts "integration", "visual activity", "theatrical activity", "creative abilities" in modern pedagogical literature is revealed. Attention is drawn to the need to train the specialists who must have the basics of knowledge in the field of related sciences; to orient in pedagogy, psychology; to be able to interact with different specialists. An attempt has been made to prove that the integration of visual and theatrical activities for senior preschool children will be an effective means of forming the creative abilities. It is emphasized that it is precisely in the preschool age that the principles of spiritual development of the child are laid, the aesthetic consciousness, the artistic culture begins to form, the content and forms of the children's activity and their enrichment are important during this period, since the child of preschool age has a need for artistic activity. It is noted that the main task of practical work of preschool educational institutions is to saturate the child's life with art, to introduce it into the world of music, fine arts, literature, theater, dance, to include art in everyday life of children, to create conditions for children's creativity.

It is noted that art represents one of the most important components of the spiritual life of mankind, artistic creativity. It is established that art combines a specific knowledge of the world in artistic images, the creation of images, the ideological content in the sensual material - in words, in motion, in paints, in space and plastic materials. It is determined that the integration of visual and theatrical-gaming activities, which are understood by the deeper form of interconnection, interpenetration of different content in the upbringing and education of children, is an important factor in the formation of artistic and creative abilities of children of the senior preschool age.

It is emphasized that creative abilities are the ability to generate new ideas, to put forward hypotheses, to fantasize, to see contradictions, to associate thinking, to transfer knowledge and skills in new situations; the integral formation of the human psyche, which is based on various personal characteristics and qualities, are systematized in relation to various types of activities performed by the individual and to a large extent determine its success in this activity; a mechanism that allows an individual to go beyond the already known way of resolving the contradiction between reproductive and productive.

Keywords: senior preschoolers; an integration; visual activity; theatrical activity; creative abilities.

П остановка проблеми. У сучасних умовах розвитку суспільства особливої актуальності набувають проблеми формування здібностей у дітей, які дозволяють їм надалі самостійно поповняти і коригувати свої знання, орієнтуватися в потоці інформації, пристосовувати свої можливості до потреб виробництва і суспільства. У Конституції 

РІЗНИХ ВИДІВ ХУДОЖНЬӦ̈-ТВОРЧОЇ ДІЯЛЬНОСТІ

України, Законах України "Про освіту”, "Про дошкільнуосвіту”, Національній доктрині розвитку освіти України в XXI столітті, Конвенції про права дитини, Положення про дошкільний навчальний заклад та програмах розвитку наголошується на необхідності формування особистості, яка характеризується високими загальнолюдськими моральними якостями, національною самосвідомістю, шанобливим ставленням до культури, мистецтва, історії, рідної мови, народних звичаїв тощо. До того ж в умовах подальшої гуманізації й індивідуалізації дошкільної освіти проблема формування та розвитку здібностей дітей набуває соціальної значущості у контексті підготовки їх до школи.

Проблема розвиткуздібностей у дітей знайшла широке відображення у психолого-педагогічному досвіді (Ш. Амонашвілі, І. Волощук, О. Кульчицька, Н. Лейтес, М. Лещенко, О. Леонтьєв, Н. Ліфарєва, О. Музика та ін.). Різні аспекти проблеми формування творчих здібностей особистості висвітлено у дослідженнях О. Кононко, Л. Масол, Н. Миропольської та ін. [13; 14; 15].

Проведений аналіз науково-методичної літератури і практика свідчать, що нині накопичений певний досвід використання поліфункціональних можливостей розвитку творчих здібностей дошкільників. Водночас недостатньо розкриті можливості інтеграції різних видів діяльності з метою формування творчих здібностей старших дошкільників.

Мета статті - аналіз розв'язання проблеми розвитку творчих здібностей дитини дошкільного віку засобами інтеграції образотворчої та музично-театральної діяльності в працях вітчизняних і зарубіжних учених.

Виклад основного матеріалу. Дошкільний вік - це період коли починає здійснюватися становлення і розвиток творчої, діяльнісної, компетентної особистості, що стає метою дошкільної освіти. Саме в дошкільному віці закладаються основи духовного розвитку дитини, починає формуватися естетична свідомість, художня культура. Важливе значення в цей період мають зміст і форми дитячої діяльності та їх збагачення, оскільки у дитини дошкільного віку 3'являється потреба в художній діяльності.

Головне завдання практичної роботи дошкільних навчальних закладів - наситити життя дитини мистецтвом, вводити ії в світ музики, образотворчого мистецтва, літератури, театру, танцю, включати мистецтво в повсякденне життя дітей, створювати умови для дитячої творчості. Адже мистецтво являє одну 3 найважливіших складових духовного життя людства, художньої творчості. Саме в мистецтві поєднується специфічне пізнання світу в художніх образах, створення зображень, ідейний зміст в чуттєвому матеріалі - в слові, в русі, в фарбах, в просторі, пластичних засобах. Відповідно до цих визначенням можна сказати, що естетичне виховання і освіта, засноване на пізнанні мистецтва, грає особливо важливу роль на етапі становлення особистості дитини, та відбувається це саме в дошкільному дитинстві. За визначенням Я.А. Коменського, мистецтво $є$ тією сферою, де можливий прояв здібностей i обдарувань людини [10, 34].

Слід зазначити, що інтеграція образотворчої і театрально-ігрової діяльності, під якими ми розуміємо більш глибоку форму взаємозв'язку, взаємопроникнення різного змісту в вихованні та освіті дітей, являється важливим фактором у формуванні художньо-творчих здібностей дітей старшого дошкільного віку.

Загалом у науковій літературі по-різному розуміють творчі здібності: як здібність генерувати нові ідеї, висувати гіпотези, фантазувати, бачити суперечності, асоціативно мислити, переносити знання і вміння в нові ситуації $[15,10]$; як інтегральне угворення психіки людини, в основі якого лежать різні особистісні властивості й якості, систематизовані по відношенню до різних видів діяльності, які виконує індивідуум і значною мірою обумовлюють його успішність у цій діяльності (В. Андрєєв, 1988); як механізм, який дає можливість індивідууму вийти за межі вже відомого шляхом вирішення протиріччя між репродуктивним і продуктивним (О. Лук, 1978).

Г. Сухорукова наголошує на нерозривному взаємозв'язку творчих здібностей індивідуума 3 вже наявними у нього знаннями, попереднім життєвим досвідом. На думку автора, розвиток творчих здібностей $є$ необхідною передумовою продуктивного перетворення вже існуючих продуктів свідомості для створення нових. Саме тому, з їх розвитком тісно пов'язані феномени уяви, фантазії, креативності активізація творчих здібностей особистості $[14,34]$.

Слід зазначити, що творчі здібності- це прояв творчої активності, спрямованої на створення прекрасного в будь-якому виді діяльності, що виражається в прагненні ясніше відобразити задумане зміст і передати образ, предмети і явища.

На сформованість творчих здібностей у дітей дошкільного віку впливає процес інтеграції, при якому відбувається цілісне художньо-естетичне уявлення дітей $[7,67]$.

У формуванні особистості дитини великого 


\section{ФОРМУВАННЯ ТВОРЧИХ ЗДІБНОСТЕЙ СТАРШИХ ДОШКІЛЬНИКІВ ЗАСОБАМИ ІНТЕГРАЦЇ̈ РІЗНИХ ВИДІВ ХУДОЖНЬОЇ-ТВОРЧОЇ ДІЯЛЬНОСТІ}

значення приділяє естетичному вихованню А. Луначарський. Він підкреслює, що естетичний зміст має пронизувати всю життєдіяльність дітей, тому автор відводить чільне місце мистецтву.

Особливе місце в контексті художньоестетичного виховання надають мистецтву закордонні вчені (Т. Грін, У. Морріс, Р. Мюллер, Я. Фальке, М. Шаслер). Так, Рут Мюллер, досліджуючи питання про те, що дозволить поліпшити роботу з художнього виховання в цілому, приходить до висновку, що для цього необхідне оволодіння дітьми всіма комплексами знань, умінь і здібностей. У цей комплекс автор включає здатність дітей глибоко переживати побачене. Для створення зображення важливо також отримання образотворчих уявлень про речі і явища навколишнього світу, розвиток спостережливості дітей, вміння виділяти істотне в предметах $\mathrm{i}$ явищах, помічати характерне для того чи іншого предмета.

Інтеграція сприяє засвоєнню знань, умінь, навичок і розвитку творчих здібностей, усуває перевантаження дітей і дорослих, розширюючи i поглиблюючи їх соціально-моральний і естетичний досвід [2, 59].

Під керівництвом Т. Комарової з'являються роботи по інтеграції образотворчої діяльності та музики; Л. Артемова - ігри-драматизації та образотворчої діяльності; Е. Трусова - природи і образотворчої діяльності. В цих дослідженнях простежується глибокий і різнобічний взаємозв'язок різних видів мистецтва і художньо-творчої діяльності дітей (образотворчої, музичної, театралізованої, ігрової, художньо-мовленнєвої та ін.) [1;8].

Проблема синтезу мистецтв в різні часи хвилювала педагогів та філософів (А. Андрєєв, В. Ванслов, Б. Галєєв, Н. Голота, М. Каган, О. Комаровська О. Мазаєв, В. Міхальов і інші) тому, що художня культура виступає як компонент освітнього процесу, а мистецтво є фактором формування особистості [9; 14].

Питанню естетичного виховання в педагогіці завжди приділялося досить багато уваги. Філософсько-естетичні аспекти розглядаються в наукових працях Ю. Афанасьєва, М. Кагана. Психологічні основи естетичного виховання висвітлюються у дослідженнях Л. Божович, Л. Виготського, Б. Тєплова. Теорія естетичного виховання дошкільників сформована на основі наукових висновків Н. Вєтлугіної, О. Запорожець, Н. Сакуліної, Т. Комарової, В. Котляра, Г. Підкурганної, В. Ждан, Є. Фльоріної. Внесок видатних педагогів минулого у вирішення окремих проблем естетичного виховання підростаючого покоління розкрито у роботах Н. Дем'янко,
О. Джус, Л. Іванової, С. Морозової, А. Соколової, Є. Федотова, І. Фрайта та інших [4; 6; 8].

Криза естетичної культури суспільства, що спостерігається в наш час, знаходиться в безперечному зв'язку з кризовими явищами культурного і духовно-орієнтаційного характеру. Виникає насущна необхідність в глибокому науково світоглядному переосмисленні уявлень про методологічні підходи до естетичного виховання дітей дошкільного віку, як в умовах дошкільного навчального закладу, так і в умовах сім’і. В умовах зниження естетичної культури дорослого і дитячого населення України, падіння моральної і загальної культури, формування духовно здорової особистості, яка має уявлення про естетику у всіх можливих проявах, набуває особливої актуальності.

За допомогою мистецтва здійснюється, в основному, передача духовного досвіду людства. В свою чергу, синтез мистецтв допомагає дітям побудувати цілісну картину навколишнього світу, усвідомити власну значущість, полегшує прийняття правильного рішення в різних життєвих ситуаціях.

Дошкільний вік дуже складний і важливий період у формуванні та становленні особистості дитини. У цей період формується характер дитини, розвиваються сенсорні процеси, пам'ять, увага, мислення, уява; здійснюється iї всебічний розвиток. Величезне значення мають різні види діяльності дітей для оволодіння різними вміннями, різними формами людської діяльності. Чим різноманітніша діяльність дитини, тим багатосторонній шлях пізнання навколишнього та розвитку їі можливостей $[1 ; 8]$.

У дошкільному віці в дітей формуються різноманітні здібності: інтелектуальні, творчі, конструктивні. Художня діяльність впливає на всебічний розвиток і формування особистості та включає в себе музичну, образотворчу, художньомовленнєву, театрально-ігрову діяльності. Кожен 3 цих видів діяльності вносить свій зміст, розкриваючи суть художньої діяльності, що спрямовано на художньо-естетичний розвиток дітей. Саме в процесі цих видів діяльностей створюються можливості формування творчих здібностей [2; 14$]$.

У дошкільному навчальному закладі художнє виховання здійснюється шляхом виховання здатності безпосередньо естетично сприймати явища дійсності, через ознайомлення 3 мистецтвом і включенням дітей в художню діяльність: спів, танці, читання віршів і розповідання казок, ігри-драматизації, малювання, ліплення. 

РІЗНИХ ВИДІВ ХУДОЖНЬОЇ-ТВОРЧОЇ ДІЯЛЬНОСТІ

Ці шляхи тісно пов'язані між собою, вони є основою успішного здійснення всіх видів художньої діяльності. Отже, розвиток у дітей здатності художнього сприйняття викликає необхідність збагачувати їх відповідними враженнями, знайомити 3 ідейно і художньо повноцінними творами мистецтва, які доступні дитячому розумінню. Діючи на свідомість і почуття, мистецтво сприяє не тільки художньому розвитку, а й розумовому та моральному вихованню [4; 7].

Досвід і дослідження показують, що комплексне використання мистецтв у роботі 3 дітьми дошкільного віку в художній діяльності, а саме інтеграції театрально-ігрової та образотворчої діяльностей, необхідне для формування і розвитку елементів естетичної культури.

Одним 3 важливих елементів естетичної культури є естетичне почуття і естетичний смак. Естетичне почуття визначається, як суб'єктивне переживання оцінного ставлення до предметів або явищ. Естетичний смак визначається як суб'єктивне освоєння об'єктивних нормативів, оцінок прекрасного і потворного. До того ж формується він протягом усього життя людини. Естетичний смак можна визначити, як здатність людини розуміти і оцінювати естетичні особливості предметів, явищ природи, суспільного життя. При цьому висловлюється оцінка дійсності, всього різноманіття естетичних цінностей з позицій вироблених у людини в процесі суспільної практики, а також уявлень про прекрасне, потворне, смішне, трагічне [7; 8].

Естетичне почуття розглядається, як специфічне переживання, що викликається в людині сприйняттям естетичної своєрідності навколишньої дійсності: краси і потворності, піднесеного і неземного, трагічного і комічного в суспільних відносинах, в поведінці людей, в мистецтві.

Отже, матеріальне вираження сформованих образів служить прекрасним засобом перевірки і збагачення їх. Треба постійно заохочувати дитячу творчість, в якій би формі воно не виражалося. Образотворча діяльність має великий вплив на розвиток у дітей елементів естетичної культури i сприяє формуванню творчих здібностей.

Варто зауважити, що діти дуже сприйнятливі до будь-якого виду художньої діяльності, тим більше до образотворчої діяльності. Образотворча діяльність $є$ однією з найцікавіших для дітей дошкільного віку, оскільки глибоко хвилює дитину та викликає позитивні емоції [5; 14].

Молодь і ринок №1 (168), 2019
Багато педагогів і психологів вважають, що образотворча діяльність є найважливішим засобом естетичного виховання (Н. Ветлугіна, Н. Венгер, І. Демченко, Л. Срмолаєва-Томіна, Б. Ліхачов, Г. Сухорукова). Образотворчу діяльність вони визначають як творчу діяльність, спрямовану не лише на відображення вражень, отриманих в житті, але і на вираз свого ставлення до зображуваного [3; 5; 6; 14].

У своїй творчості діти передають ті естетичні якості предметів, які вони побачили і виділили в процесі сприйняття. Створюючи малюнок, ліплення, аплікацію, діти відзначають, чому їм подобаються зображення, що в них цікавого, чому вони радують їx, i, навпаки, що викликає негативне ставлення. Слід зазначити, що естетична оцінка часто переплітається 3 моральною. Тому вираз ставлення до зображення - це прояв не тільки естетичної оцінки, а й громадської спрямованості творчості у дітей дошкільного віку, що має важливе значення для морального виховання дітей.

У процесі образотворчої діяльності створюються сприятливі умови для розвитку естетичного, емоційного сприйняття мистецтва, що сприяє формуванню естетичного ставлення до дійсності і до мистецтва. Спостереження та виділення властивостей предметів, які належить передати в зображенні (форми, будови, величини, кольору, розташування у просторі), сприяють розвитку у дітей естетичного почуття, формуванню образних уявлень, уяви. Образотворча діяльність має свої особливості саме в дошкільному дитинстві тому, що у дошкільнят розвивається творча активність, діти починають створювати оригінальні продукти своєї діяльності [7; 14].

Емоційне ставлення до об'єктів естетичного характеру, емоційне ставлення до художньої діяльності $\epsilon$ найважливішим чинником формування у дітей творчості в образотворчій діяльності і естетичному вихованні в цілому.

Емоційне позитивне ставлення до творів мистецтва (картини, скульптури, фотографії), до своїх робіт і робіт своїх однолітків служить основою будь-якої діяльності та є важливою умовою виховання елементів естетичної культури в театрально-ігрової та образотворчої діяльності.

В результаті взаємозв'язку образотворчої та театрально-ігрової діяльності, їх взаємовпливу, збагачується особистість дитини, розвивається іiі естетична культура, формуються художньотворчі здібності. Виховні можливості театралізованої діяльності дуже широкі. Беручи участь в ній, діти знайомляться 3 навколишнім 


\section{ФОРМУВАННЯ ТВОРЧИХ ЗДІБНОСТЕЙ СТАРШИХ ДОШКІЛЬНИКІВ ЗАСОБАМИ ІНТЕГРАЦЇ РІЗНИХ ВИДІВ ХУДОЖНЬӦ̈-ТВОРЧОЇ ДІЯЛЬНОСТІ}

світом у всьому його різноманітті через образи, фарби, звуки, а вміло поставлені питання змушують їх думати, аналізувати, робити висновки i узагальнення. Театралізована діяльність є джерелом розвитку почуттів, глибоких переживань і відкриттів дитини, прилучає iii до духовних цінностей $[12,2]$.

Театралізовані заняття розвивають емоційну

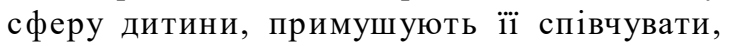
співпереживати. Театр - це синтетичний вид мистецтва, в якому можна успішно поєднувати багато видів дитячої діяльності. Об'єднання діяльностей можливо тому, що атмосфера театру - це природна стихія для дитини. Саме театр дозволяє реалізовувати і розвивати величезні творчі і емоційні можливості дітей, не завжди затребувані повсякденним життям [9; 11; 12].

Театралізована діяльність - найважливіший засіб розвитку у дітей емпатії - здатності розпізнати емоційний стан людини по міміці, жестах, інтонації, уміння ставити себе на його місце, знаходити адекватні способи дії.

В театралізованій діяльності дитина не тільки отримує інформацію про навколишній світ, закони суспільства, про красу людських відносин, а й вчиться жити в цьому світі, будувати свої відносини. Для того, щоб вирішити ці життєві завдання від дитини потрібно головне - творча активність особистості, сформованість художньотворчих здібностей (уваги, уяви, логіки, емоційної пам'яті, добре розвиненого мовлення, міміки).

Різнобічний вплив театралізованих ігор на особистість дитини дозволяє використовувати їх як специфічний педагогічний засіб, оскільки саме в грі дитина відчуває себе більш розкуто, вільно, природно. У зв'язкуз чим, театралізовану діяльність прийнято називати театрально-ігровою $[5,35]$.

Вважаємо за необхідне визначити основні принципи побудови інтеграційного процесу образотворчої та театрально-ігрової діяльності:

- ретельний відбір і доступність матеріалу емоційного досвіду дитини і досвіду сприйняття;

- активна творча діяльність дітей;

- облік індивідуальних уподобань та інтересів; взаємозв'язок всіх педагогів дитячого закладу;

- естетика предметно-розвиваючого середовища (оформлення вистави, дитячого святкового ранку, дитячих робіт).

Працюючи в системі інтеграції вищезазначених видів діяльності, педагогу необхідно: створювати умови для розвитку творчої активності дітей; залучати дітей до художньої культури; створювати умови для спільної діяльності дітей і дорослих; забезпечувати взаємозв'язок діяльності в єдиному педагогічному процесі.
Слід вказати про необхідність створення певних умов, оскільки тільки спеціальна організація зазначених видів діяльностей допоможе в процесі роботи вибрати найкращі напрямки, форми і методи.

Отже, створення величезного творчого простору сприятиме реалізації нових форм спілкування з дітьми, індивідуальному підходу до кожної дитини, нетрадиційним шляхам взаємодії з сім'єю і взагалі цілісності педагогічного процесу та форм його реалізації. Це в свою чергу сприятиме збагаченню духовного світу дитини; розкриттю індивідуальних здібностей дітей; розвиненню основних психічних процесів.

\section{ЛІТЕРАТУРА}

1. Артемова Л. В. Національний дитячий садок на Україні / ред. жур. Дошкільне виховання, 1991. -№6 -115 c.

2. Біла І. М. Психологія дитячої творчості. Фенікс, - 2014. - 137 с.

3. Венгер Н. А. Восприятие и обучение: Дошкольный возраст. / Просвещение, - 1980. $67 \mathrm{c}$.

4. Ветлугина Н. А. Эстетическое воспитание в детском саду. / Просвещение, - 1978. - 53 с.

5. Демченко I. I. До проблеми творчого розвитку дітей засобами образотворчого мистецтва. Актуальність проблеми формування особистості нового типу / Всеукраїнська науковопрактична конференція Збірник матеріалів. Кременець: КОГПІ ім. Тараса Шевченка, - 2002. - C.35-37.

6. Запорожец А. В. Избр. психологические труды. В 2 т. Педагогика, 1986. - Т. 1. - 234c.

7. Здібності, творчість, обдарованість: теорія, методика, результати досліджень / За ред. В.О. Моляко, О.Л. Музики. Житомир. Вид-во Рута, 2006. $-320 \mathrm{c}$.

8. Комарова Т. С. Дети в мире творчества: кн. для педагогов дошк. учреждений. Присвещение, $-1995 .-160 \mathrm{c}$.

9. Комаровська О.А. Театральне мистецтво в курсі “Художня культура України”. / Мистецтво і освіта. - 2002. - № 2. - С. 26-9.

10. Коменский Я.-А. Избранные собрания сочинений. / Педагогика, - 1948. -Т. 3. -178 с.

11. Кульчицкая Е. И. Одаренность как психологическая проблема. / Практична психологія та соціальна робота, - 2001. - №7. C. 28-30.

12. Масол Л. М. Виховний потенціал мистецтва - джерело освітніх інновацій. / Мистецтво і освіта,- 2001. - № 1. - С. 2-5.

13. Момот Л., Шелестова Л. Творчий розвиток 
учнів у процесі навчання. / Шлях освіти, - 2002. № 3.- С. 10-12.

14. Сухорукова Г.В., Дронова О.О., Голота Н.М., Янцур Л.А. Образотворче мистецтво з методикою викладання в дошкільному навчальному закладі. / За заг. ред. Г.В. Сухорукової. Слово, $-2010 .-376$ с.

\section{REFERENCES}

1. Artemova, L. V. (1991). Natsionalnyi dytiachyi sadok na Ukraini [National Kindergarten in Ukraine]. Preschool education, No.6, 115p. [in Ukrainian].

2. Bila, I. M. (2014). Psykholohiia dytiachoi tvorchosti [Psychology of children's creativity]. Feniks, 137 p. [in Ukrainian].

3. Venger, N. A. (1980). Vospriyatie i obuchenie: Doshkolnyy vozrast [Perception and learning: Preschool age]. Enlightenment, 67p. [in Russian].

4. Vetlugina, N. A. (1978). Esteticheskoe vospitanie v detskom sadu [Aesthetic education in kindergarten]. Prosveshchenie, 53p. [in Russian].

5. Demchenko, I. I. (2002). Do problemy tvorchoho rozvytku ditei zasobamy obrazotvorchoho mystetstva. Aktualnist problemy formuvannia osobystosti novoho typu [To the problem of creative development of children by means of fine arts. Relevance of the problem of forming a person of a new type]. All-Ukrainian Scientific and Practical Conference. Collection of materials. Kremenets: KOHPI im. Tarasa Shevchenka, pp.35-37. [in Ukrainian].

6. Zaporozhets, A. V. (1986). Izbr. psikhologicheskie trudy. V 2 t. [Fav. psychological works]. Pedagogy, Vol. 1, 234p. [in Russian].

7. Zdibnosti, tvorchist, obdarovanist: teoriia, metodyka, rezultaty doslidzhen (2006). [Ability, creativity, giftedness: theory, methodology, research results]. Zhytomyr. Vyd-vo Ruta. 320p. [in Ukrainian].

8. Komarova, T. S. (1995). Dety v myre tvorchestva: kn. dlia pedahohov doshk. uchrezhdenyi [Children in the world of creativity: the book. for teachers DOSK. institutions]. Prosveshchenie, 160 p. [in Ukrainian].

9. Komarovska, O. A. (2002). Teatralne mystetstvo v kursi "Khudozhnia kultura Ukrainy" [Theatrical art in the course "Art culture of Ukraine”]. Mystetstvo i osvita. No. 2, pp. 26-39. [in Ukrainian].

10. Komenskiy, Ya.-A. (1948). Izbrannye sobraniya sochineniy [Selected Collected Works]. Pedagogy. Vol. 3, 178p. [in Russian].

11. Kulchitskaya, Ye. I. (2001). Odarennost kak psikhologicheskaya problema [Giftedness as a psychological problem]. Practical Psychology and Social Work, No.7, pp. 28-30. [in Russian].

12. Masol, L. M. (2001). Vykhovnyi potentsial mystetstva - dzherelo osvitnikh innovatsii [Educational potential of art - a source of educational innovation]. Art and Education, No.1, pp. 2-5. [in Ukrainian].

13. Momot, L. \& Shelestova, L. (2002). Tvorchyi rozvytok uchniv u protsesi navchannia [Creative development of students in the process of learning]. Education path, No. 3, pp. 10-12. [in Ukrainian].

14. Sukhorukova, H. V., Dronova, O. O., Holota, N. M. \& Yantsur, L. A. (2010). Obrazotvorche mystetstvo $\mathrm{z}$ metodykoiu vykladannia $\mathrm{v}$ doshkilnomu navchalnomu zakladi [Fine art with a teaching method in a preschool educational institution]. Word, $376 \mathrm{p}$. [in Ukrainian].

Стаття надійшла до редакції 11.12.2018

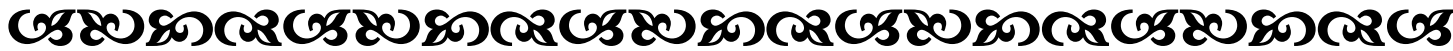

"Світ постає пери за все як неперервний розвиток минулого, яке вбирає в себе майбутнє та розиирюється в міру руху вперед”.

\section{АнріБерасон франиузький ббілософ}

"У житті немає нічого, чого варто було б боятися. С тільки те, що потрібно зрозуміти".

Марія Склодовська-Кюрі франиузький бозик хімік, педагог

“Всі перешкоди і труднощі - це щаблі, по якихми ростемо вгору”. Фрідріх Hiume німецький білособб, психолог

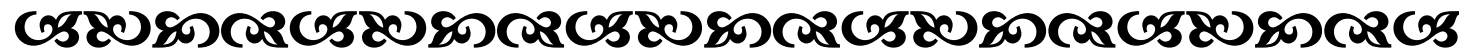

Молодь і ринок №1 (168), 2019 